\title{
The Wishes and Expression of Gratitude of Youth ${ }^{1}$
}

\author{
Jonathan Richard Henry Tudge ${ }^{2}$ \\ University of North Carolina at Greensboro, \\ NC, United States of America \\ Irina L. Mokrova \\ University of North Carolina at \\ Chapel Hill, NC, \\ United States of America \\ Yudan Chen Wang \\ University of North Carolina \\ at Greensboro, NC, \\ United States of America
}

\author{
Lia Beatriz de Lucca Freitas \\ Universidade Federal do Rio Grande do Sul, \\ Porto Alegre-RS, Brazil
}

\author{
Marion O'Brien \\ University of North Carolina \\ at Greensboro, $N C$, \\ United States of America
}

\begin{abstract}
Little research has examined the development of gratitude in youth, and none has related their gratitude to their wishes. We therefore asked 358 7- to 14-year-old North American participants (56\% female; 55\% White) to write their greatest wish and what they would do for their benefactor. Using chi-square and linear curve estimation, we found that younger youth (aged 7 to 10) were significantly more likely to express hedonistic wishes (desire for immediate gain) and concrete gratitude (not taking the benefactor's wishes into account); older youth (aged 11 to 14) were significantly more likely to wish either for something involving future well-being for themselves or the well-being of others and connective gratitude (taking into account the benefactor's wishes). Within both age groups, there was a significant inverse relation between hedonistic wishes and connective gratitude. This research has implications for encouraging the feeling and expression of connective gratitude.
\end{abstract}

Keywords: gratitude, child development, adolescent development

\section{Os Desejos e a Expressão de Gratidão dos Jovens}

\begin{abstract}
Resumo: Poucos estudos examinaram o desenvolvimento da gratidão em jovens, e nenhum estabeleceu relações entre sua gratidão e seus desejos. Assim, solicitamos a 358 participantes norte-americanos entre 7 e 14 anos de idade (56\% meninas; 55\% brancos) que escrevessem qual seria o seu maior desejo e o que eles fariam a seu benfeitor. Utilizando qui quadrado e estimativa de curva linear, encontramos que os mais jovens (de 7 a 10 anos de idade) foram significativamente mais propensos a expressar desejos hedonistas (desejo por ganho imediato) e gratidão concreta (não considerando os desejos do benfeitor); os jovens mais velhos (de 11 a 14 anos de idade) foram significativamente mais propensos a desejar seja algo envolvendo bem-estar futuro para si mesmos seja o bem-estar de outros e gratidão conectiva (levando em conta os desejos do benfeitor). Em ambos os grupos etários, houve uma relação inversa significativa entre desejos hedonistas e gratidão conectiva. Esta pesquisa tem implicações para encorajar o sentimento e a expressão de gratidão conectiva.
\end{abstract}

Palavras-chave: gratidão, desenvolvimento infantil, desenvolvimento do adolescente

\section{Los Deseos y la Expresión de la Gratitud en los Jóvenes}

\begin{abstract}
Resumen: Pocos estudios han examinado el desarrollo de gratitud en los jóvenes, y ninguno ha relacionado su gratitud a sus deseos. Por lo tanto, pedimos a 358 participantes de América del Norte de 7 a 14 años de edad (55\% femenino, 55\% blanco) a escribir su mayor deseo y lo que harían por su benefactor. Utilizando un distribución ji-cuadrado y estimación curva lineal, encontramos que los más jóvenes (de 7 a 10 años de edad) fueron significativamente más propensos a expresar los deseos hedonistas (deseo de ganancia inmediata) y la gratitud de concreto (no tomar los deseos del benefactor en cuenta); los jóvenes mayores (de 11 a 14 años de edad) fueron significativamente más propensos a desear sea para algo relacionado con el bienestar futuro para sí mismos o para el bienestar de los demás y gratitud conectivo (tomando en cuenta los deseos del benefactor). Dentro de ambos grupos de edad, existe una relación inversa significativa entre los deseos hedonistas y gratitud conectivo. Esta investigación tiene implicaciones para fomentar el sentimiento y la expresión de gratitud conectivo.
\end{abstract}

Palabras clave: gratitud, desarrollo infantil, desarrollo del adolescente

\footnotetext{
${ }^{1}$ Acknowledgement: We would like to express our gratitude to the youth who participated in this study.

Support: The first author received support from the Coordination for the Improvement of Higher Education Personnel (CAPES - Grant no. BEX18344/12-7) and The John Templeton Foundation (Grant no. 43510); the second author was supported by the National Council for Scientific and Technological Development (CNPq - Grant no. 301714/2012-6).

${ }^{2}$ Correspondence address:

Jonathan Tudge. Dept. of Human Development and Family Studies. University of North Carolina at Greensboro, NC 27402-6170, USA. E-mail: jrtudge@uncg.edu
}

Gratitude is a socially desirable trait valued in many cultures for its role in strengthening social bonds. Parents encourage children to express gratitude, and ungrateful individuals are viewed negatively. Gratitude has been defined in at least two ways. Some include in the definition positive feelings about the good things that life offers such as beautiful sunsets or good health, or being grateful to God (Froh, Yurkewicz, \& Kashdan, 2009; Wood, Froh, \& Geraghty, 2010). Others, in both psychology and philosophy, 
have defined gratitude more specifically as positive feelings towards and desire to repay a benefactor who has intentionally and freely provided a gift or help, without requesting or requiring payback (Baumgarten-Tramer, 1938; McConnell, 1993, 2013). We use this latter definition, which is also the one accepted by psychologists who were among the first to conduct empirical research on gratitude (BaumgartenTramer, 1938) as well as by recent scholars (Freitas, Pieta, \& Tudge, 2011; Froh, Bono, \& Emmons, 2010; McCullough, Kimeldorf, \& Cohen, 2008; Rava \& Freitas, 2013).

The sense of connection to a benefactor and desire to reciprocate are key components of gratitude in that they contribute to a positive cycle of giving or helping. In the course of repaying the benefactor, the original beneficiary becomes a benefactor as well, and the cycle repeats, thus helping to form ever-closer relations between the individuals concerned. This positive cycle has been recognized in humans (Piaget, 1954/1981) and may also occur in nonhuman primates (Bonnie \& de Waal, 2004).

Gratitude is present in the life of youth who live in different contexts (Paludo, 2014), features as a part of young adolescents' conceptions of what it takes to be considered a moral person (Hardy, Walker, Olsen, Skalski, \& Basinger, 2011), and develops during childhood and adolescence (Baumgarten-Tramer, 1938; Freitas et al., 2011; Piaget, 1954/1981) as children form a theory of mind, are able to think in non-egocentric ways, and can take into account others' intentionality (Kawashima \& Martins, 2015). We should thus expect youth of different ages to express gratitude in different ways. Young children can be taught to say "thank you", but a learned social convention is not the same as the more sophisticated type of gratitude fitting with the definition we have used. Older children may learn that one should reciprocate in some way beyond saying "thank you" for help or gifts received. However, reciprocation in a way designed to be helpful or pleasurable to the benefactor requires taking another's perspective; egocentric children or those who show little understanding of theory of mind are unlikely to express gratitude in its most sophisticated form (Freitas, O'Brien, Nelson, \& Marcovitch, 2012; Nelson et al., 2013). Adolescents are more likely than younger children to take into account benefactors' intentions (Weiner \& Graham, 1988) and thus should be more likely to express the more sophisticated type of gratitude than are younger children. One of the main aims of this study is to test this hypothesis.

To date, the development of gratitude has received little empirical focus, with research mainly on adults (Freitas et al., 2011). Among adults, gratitude is related to individuals' sense of well-being and quality of life (Emmons \& Mishra, 2012; Wood et al., 2010): individuals who more often experience and express gratitude report being happier; enjoying their work more; being more optimistic, energetic, and helpful; and having lower levels of depression and stress than those who do not (Kerr, O’Donovan, \& Pepping, 2015; McCullough, Emmons, \& Tsang, 2002). In adolescents gratitude is related to life satisfaction, contentment, optimism, and positive affect (Algoe, 2012; Algoe, Fredrickson, \& Gable, 2013; Froh et al., 2009). Experimental studies have shown that youth who are encouraged to express gratitude subsequently feel more positive about their school, teachers, and friends (Bono \& Froh, 2009; Froh et al., 2014).

Much of this research, however, does not treat gratitude as the "positive feeling towards and desire to repay a benefactor", as described above. Except for studies in which gratitude is induced by having participants write a letter to someone who has helped them in some way (Froh et al., 2014), the most widely used measures are the Gratitude Questionnaire (McCullough et al., 2002), most items of which are not related to a benefactor, or the Gratitude Adjective Checklist (McCullough et al., 2002), which asks participants the extent to which they feel grateful, thankful, and appreciative over the previous 24 hours, without any reference to a benefactor. A different type of measure is needed to assess gratitude towards a benefactor (Gulliford, Morgan, \& Kristjánsson, 2013). Moreover, none of these studies are designed to examine the development of gratitude.

In the first study designed specifically to examine the development of gratitude, Baumgarten-Tramer (1938) asked 1,059 7- to 15-year-old Swiss participants to state their greatest wish and what they would do for a benefactor who granted that wish. Responses to the second question were categorized as: verbal gratitude (e.g., "thank you"); concrete gratitude (providing the benefactor something valuable to the beneficiary, such as offering a doll in return for a game); and connective gratitude (providing something valuable to the benefactor, such as saying "I would do whatever I could to help her"). Baumgarten-Tramer found that verbal gratitude was common at all ages but most frequent among 15-yearolds, concrete gratitude was more common in her younger than older participants, and connective gratitude was more common in those who were older. Connective gratitude, as the name suggests, should help build or maintain relationships with others and is the most sophisticated type.

Recent research using Baumgarten-Tramer's (1938) method has supported her findings with data from 430 Brazilian children and young adolescents (Freitas et al., 2011). In this study verbal gratitude was expressed at all ages but most frequently by $12-$ and 14 -year-olds. Children (7- to 10 -year-olds) were more likely to express concrete gratitude whereas adolescents (11- to 14-year-olds) were more likely to express connective gratitude. Neither study provided data on the types of wishes the participants had. One might expect, however, some link between children's wishes and their gratitude. For example, youth who wish for something that is designed to benefit others may be more likely to express connective gratitude than those who wish for something of benefit to themselves. The content of youths' wishes is also likely to vary by age. It is possible that adolescents' more sophisticated expressions of gratitude are related to the nature of their wishes, which may focus less on material objects than those of younger children. Support for this idea comes from research by Chaplin and John (2007) who found 12- to 13-year-olds chose more material objects to place in a collage than did either 8- to 9-year-olds or 16- to 18 -yearolds. They interpreted their findings to show age differences in materialism. 
Gratitude researchers have generally not examined gender or ethnic differences. In one study girls were found to be more likely to express gratitude for interpersonal events such as being helped, whereas boys were more likely to express gratitude for material things (Gordon, MusherEizenman, Holub, \& Dalrymple, 2004). Such a finding is supported by other research into American adolescents' values, showing that females are less materialistic than are males (Goldberg, Gorn, Peracchio, \& Bamossy, 2003; Kasser, 2005). Kashdan, Mishra, Breen, and Froh (2009) found that adult women were more likely to express gratitude than were men, and women who expressed more gratitude were more likely to feel a sense of connectedness with others. No studies have examined cultural or ethnic variation in the expression of gratitude.

\section{The Present Study}

The main goal was to examine the expression of gratitude in children and adolescents and to identify age differences in the types of gratitude expressed, rather than variations in the extent to which individuals feel grateful, the typical focus in gratitude research with adolescents and adults. However, as our aim was to assess gratitude relating to the hypothetical receipt of something wished for, we first asked our participants to identify their "greatest wish". Initially, therefore, we examined the content of our participants' wishes. We hypothesized that those who were younger would be more likely to wish for immediate hedonistic material gain (money, toys, etc.) whereas adolescents' wishes would focus on longer-term benefits such as their own future well-being or the well-being of others.

Second, we asked our participants what they would do for the person who granted them their wish. We hypothesized that those who were younger would be more likely to express concrete gratitude whereas those who were older would be more likely to express connective gratitude. We expected no age differences in verbal gratitude, as found in earlier research.

Finally, we examined the expression of gratitude in relation to participants' wishes. We anticipated that those wishing for immediate benefits for themselves (hedonistic wishes) would be more likely to express concrete gratitude, whereas those whose wishes are focused on the well-being of others would be more likely to express connective gratitude. Youths wishing for their own future well-being were expected to fall in between. Based on earlier findings, we hypothesized that girls would be less likely than boys to express hedonistic wishes and more likely than boys both to express connective gratitude and to wish for social well-being. No gender difference was expected in wishes for self well-being.

\section{Method}

\section{Participants}

A total of 358 7- to 14-year-old youths from a city in the southeastern United States participated in this study. Females (mean age 10 years 10 months, $S D=24.4$ months) comprised $56 \%$ of the sample (197) and males $44 \%$ (155) (mean age 10 years 4 months, $S D=25.7$ months) (six participants did not report gender, and were excluded from all analyses involving gender). For purposes of analysis, children were divided into younger (7-10 years) and older (11-14 years) age groups. Approximately 55\% (197) self-identified as European American (White), 33.5\% (120) as African American (Black) or Black/White bi-racial, $8.4 \%$ (30) as Hispanic or from Spanish-speaking homes, and 4\% (11) from other ethnic groups or provided no information about ethnicity. Because of the low numbers of Hispanic and other groups, they were excluded from analysis of ethnic group differences.

The participants were recruited from six public schools (three elementary and three middle schools). Although we did not collect data on social class, the schools were selected to reflect the range of SES represented by the city's public schools. Students were asked to take home, and return, a parental consent letter; we described the study to those youths whose parents had provided consent and invited them to participate. Classrooms were provided $\$ 2$ for each student who returned the parental consent letter, regardless of parental permission. The return rate was $56 \%$; $86 \%$ of these gave consent and $84 \%$ of this number participated (the remainder were absent or chose not to participate). All youths whose parents gave permission and who themselves wished to participate were allowed to do so.

\section{Instruments}

The participants were asked to respond, in writing, to the Wishes and Gratitude Survey (Freitas, Tudge, \& McConnell, 2008, derived from Baumgarten-Tramer, 1938), consisting of four open-ended questions: "What is your greatest wish?", "What will you do for the person who granted you this wish?", "Is there anything else you should do for this person?" and "Who is this person?" For this study, only the first two were coded and analyzed. The second question includes the assumption that the wish is being freely and intentionally granted, thus fitting our definition of gratitude.

\section{Procedure}

Data collection. Data collection took place in groups in the participants' classrooms at school or in a central place, such as the school library or cafeteria. Research assistants were available to help any participants who had reading difficulties and to make sure that their responses were legible. Data collection took approximately 20 to 30 minutes.

Data analysis. Responses to the first question were coded into three categories: (a) hedonism, or a desire for something that brings immediate pleasure; (b) self wellbeing, or a desire for future-related personal benefits; and (c) social well-being, or a desire for current or future benefits for others. Fourteen youths $(4 \%)$ were excluded from the analyses involving wishes as they did not provide a wish or the wish's meaning was unclear. Responses to the second question about what each respondent would do for the person who granted his or her wish were coded into the three main categories used by Baumgarten-Tramer (1938): (a) verbal gratitude ("thank you" or "I would thank him 1,000 times"); 
(b) concrete gratitude (offering the benefactor something in return, but something of value to the child and not to the benefactor; e.g., in return for being granted the wish "to become a pro basketball player," offering the benefactor an autographed basketball); and (c) connective gratitude (offering an object or help of value to the benefactor, such as: "I'll help her in any way that I can"). In addition, 32 (9\%) of the participants were coded as "other" (including no response and "don't know") and were dropped from the analyses involving gratitude.

Two of the research team (the first author and a graduate student, trained in coding both wishes and gratitude) independently coded $50 \%$ of the responses to these two questions; kappas were .82 and above for wishes, and .90 and above for gratitude. All disagreements were discussed until agreement was reached. A large majority of the participants provided a response that could be coded into just one of the possible types; in the 76 cases $(21 \%)$ in which participants provided two or more responses, the more advanced was included in the analyses.

The coded data were then analyzed using SPSS Version 18. Chi-square analysis was used to examine whether younger (7- to 10-year-olds) were more or less likely than those who were older (11- to 14-year-olds) to choose one or other type of wish and to respond with one or other type of gratitude. Chi-square analysis was also used to examine the relation between types of wishes and the types of gratitude expressed. We used curve estimation (one of the available options in SPSS for linear regression analysis) to assess the extent of age-related changes in both types of wishes and types of gratitude.

\section{Ethical Considerations}

This research project was approved by the Institutional Review Board of the University of North Carolina at Greensboro (IRB \# 11-0315), and was carried out in full compliance with all ethical considerations. Parents first needed to provide their consent before students were asked to listen to and/or read a child-assent form that clearly explained the project and their role. Only students who signed that form were permitted to engage in the research.

\section{Results}

\section{Types of Wishes}

As hypothesized, 7- to 10-year-olds were more likely than 11- to 14-year-olds to express hedonistic wishes (56\% vs. $24 \%$ ), and less likely to express wishes relating to either self-well-being ( $36 \%$ vs. $55 \%$ ) or social well-being ( $8 \%$ vs. $21 \%), \chi^{2}(2)=37.49, p<.0001$ (Figure 1 ). The two age groups differed significantly between hedonistic wishes and both self well-being $\left(\chi^{2}[1]=27.61, p<.0001\right)$ and social well-being $\left(\chi^{2}[1]=25.04, p<.0001\right)$, but not between self and social well-being $\left(\chi^{2}[1]=1.55, n s\right)$. We also ran curve-estimation analyses to test whether the relation between age and types of wishes changed in a linear fashion. As only four 14-year olds were included in our sample, the curve estimations were conducted with 3547 - to 13-year olds. The results indicated a significant linear decline in hedonistic wishes with age $\left(R^{2}=.74, p\right.$ $=.012$ ), and significant linear increases in wishes for both self well-being $\left(R^{2}=.73, p=.015\right)$ and social well-being $\left(R^{2}=.64, p=.031\right)$.

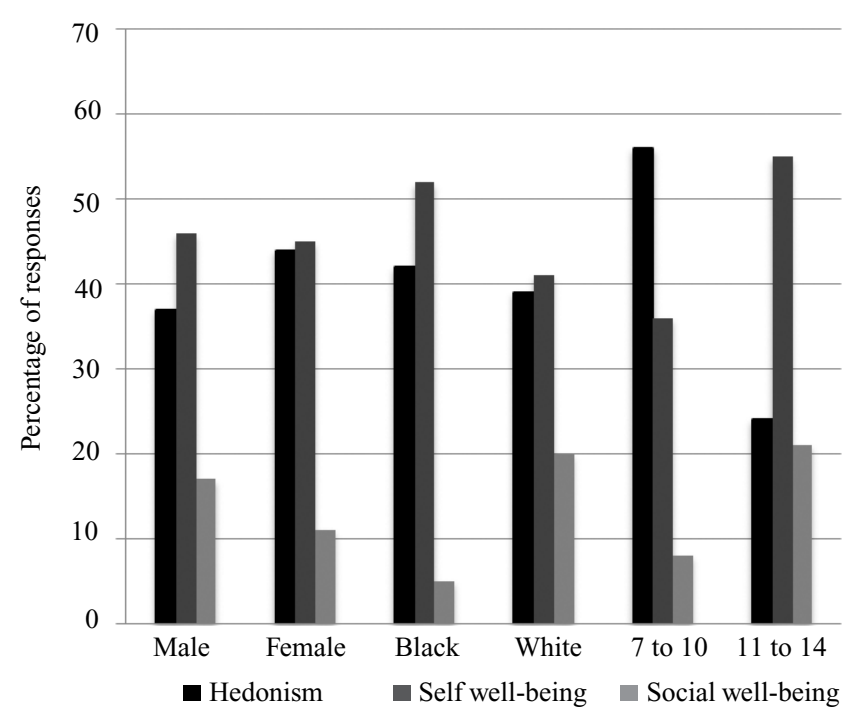

Figure 1. Percentages of expression of wishes for hedonism, futureoriented self well-being, and social well-being by gender, ethnicity, and age group.

Although we had hypothesized that fewer girls than boys would express hedonistic wishes, no significant differences were found $\left(\chi^{2}[2]=3.18, n s\right)$. We had not hypothesized ethnic variation in the participants' wishes, but we found African American youths to be more likely than their European American counterparts to wish for self well-being $(52 \%$ vs. $41 \%)$ and less likely to wish for social well-being $(5 \%$ vs. $20 \%), \chi^{2}(2)=11.83, p<.005$. No difference was found for hedonistic wishes ( $42 \%$ vs. $39 \%)$.

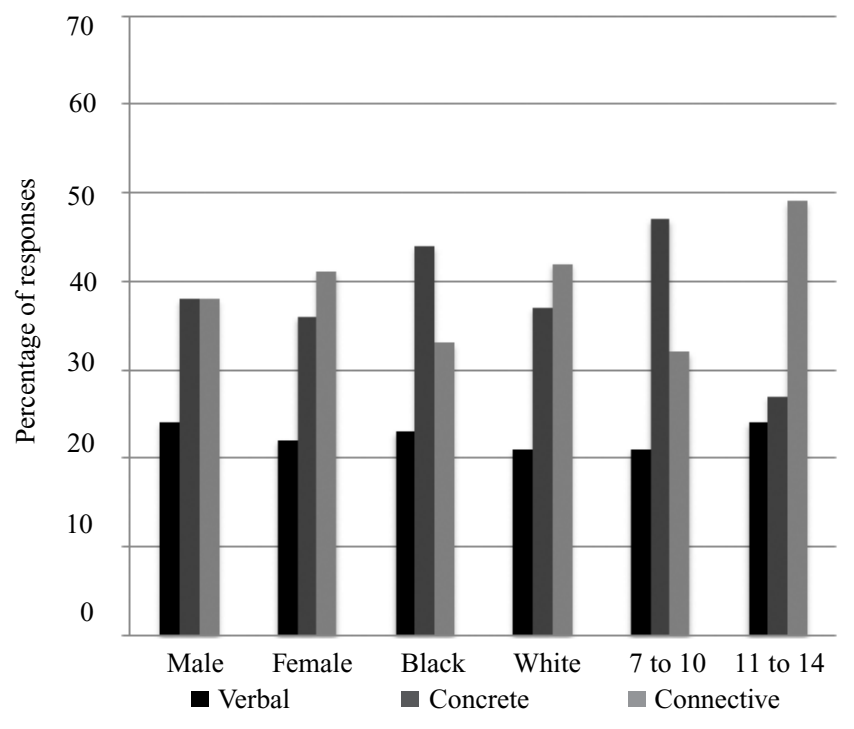

Figure 2. Percentages of responses of verbal, concrete, and connective gratitude, by gender, ethnicity, and age group. 


\section{Types of Gratitude}

As predicted, younger participants were more likely than those who were older to express concrete gratitude $(47 \%$ vs. $27 \%)$ and less likely to express connective gratitude $(32 \%$ vs. $49 \%)$, with little difference ( $21 \%$ vs. $24 \%$ ) in expression of verbal gratitude $\left(\chi^{2}[2]=14.95, p<.01\right)$ (Figure 2). To test the specific hypothesis dealing solely with concrete and connective gratitude, we reanalyzed the data without including those participants who had expressed verbal gratitude; as predicted, the younger age group $(n=119)$ was significantly more likely to express concrete gratitude and the older group $(n=119)$ significantly more likely to express connective gratitude, $\chi^{2}(1)=15.01, p=.0001$. The curveestimation analyses revealed no significant linear change in terms of verbal gratitude $\left(R^{2}=.43, p=.109\right)$, but a significant linear decline, with age, in concrete gratitude $\left(R^{2}=.76, p=\right.$ $.011)$ and a significant linear increase in connective gratitude $\left(R^{2}=.91, p=.001\right)$. We found no gender or ethnic differences in expressions of gratitude.

\section{The Connection Between Wishes and Gratitude}

Data on the relation between types of wishes and types of gratitude are in Table 1. We predicted that participants whose wishes were hedonistic would be more likely to express concrete gratitude whereas those who wished for social wellbeing would be more likely to express connective gratitude. This prediction was supported, $\chi^{2}(2)=26.87, p<.0001$. The finding also held across both age groups: younger group, $\chi^{2}(2)$ $=10.82, p=.004$; older group, $\chi^{2}(2)=10.01, p=.007$.

Table 1

The Relation Between Types of Wishes and Types of Gratitude

\begin{tabular}{lcccc}
\hline $\begin{array}{l}\text { Types of } \\
\text { gratitude }\end{array}$ & Verbal & Concrete & Connective & $n$ \\
\hline \multirow{3}{*}{ Types of wishes } & \multicolumn{4}{c}{ 7- to 10-year-olds } \\
\cline { 2 - 5 } Hedonism & $18(22 \%)$ & $45(55 \%)$ & $19(23 \%)$ & 82 \\
Self well-being & $12(21 \%)$ & $23(40 \%)$ & $22(39 \%)$ & 57 \\
Social well-being & $4(28 \%)$ & $2(14 \%)$ & $8(57 \%)$ & 14 \\
\cline { 2 - 5 } & & $11-$ to $14-y e a r-o l d s$ & \\
\cline { 2 - 5 } & $11(27 \%)$ & $13(32 \%)$ & $16(40 \%)$ & 40 \\
Hedonism & $20(23 \%)$ & $26(31 \%)$ & $39(46 \%)$ & 85 \\
Self well-being & $8(24 \%)$ & $2(6 \%)$ & $23(70 \%)$ & 33 \\
Social well-being & &
\end{tabular}

More 7- to 10-year-olds expressed hedonistic wishes $(82,53.6 \%)$ than wishes for self well-being $(57,37.3 \%)$ or social well-being $(14,9.2 \%)$ (Table 1). However, of those expressing hedonistic wishes only 19 (23\%) expressed connective gratitude, whereas 8 of $14(57 \%)$ who expressed wishes for social well-being did so. As for the 11- to 14-yearolds, the majority $(85,53.8 \%)$ expressed wishes for self wellbeing, followed by $40(25.3 \%)$ who expressed hedonistic wishes and 33 (20.9\%) who wished for social well-being.
Of the 40 expressing hedonistic wishes, 13 (32\%) expressed concrete gratitude and $16(40 \%)$ expressed connective gratitude. By contrast, of the 33 in the older group who had wished for social well-being only $2(6 \%)$ expressed concrete gratitude and $23(70 \%)$ expressed connective gratitude. As expected, the participants at both ages who wished for self well-being were more evenly divided in their expression of concrete versus connective gratitude.

\section{Discussion}

The purpose of the present research was to examine agerelated changes in the expression of three types of gratitude in youth, and the extent to which these types of gratitude were related to the participants' wishes. Verbal gratitude is the simplest form, and is found in children as young as 3 (Becker \& Smenner, 1986). It is difficult, however, to distinguish verbal gratitude from politeness. Concrete gratitude involves reciprocity in that children indicate that they should repay a favor, but, in egocentric fashion, they think that what they themselves value will also be valued by the benefactor. Connective gratitude is yet more sophisticated, and thus the most advanced, developmentally, because it requires that youth take into account the desires or needs of the benefactor. Only connective gratitude fully captures the moral sense described by Piaget (1954/1981) as the feeling that occurs when a person does not simply value the help or favor but the person who provided it.

As hypothesized, 7- to 10-year-olds were most likely to express concrete gratitude whereas 11- to 14-year-olds were most likely to express connective gratitude, with little agegroup difference in the expression of verbal gratitude. There was, however, a good deal of individual variation. About one third of the younger group expressed connective gratitude, and a just over one quarter of the older group expressed concrete gratitude. Nonetheless, the findings provide evidence that with development comes a greater propensity to express gratitude in a way that involves forming or strengthening a bond with a benefactor.

We wanted to know the extent to which the participants' wishes varied by age. Our data support our hypothesis that younger children are more likely than those who are older to wish for things that benefit themselves fairly immediately and less likely to wish for things that are related to their own future well-being or the well-being of others. As with gratitude, there was a good deal of individual variability. Although a majority of the younger group's wishes were coded as hedonistic, more than a third wished for something that involved future-oriented self well-being and some wished for something that would benefit the wider community. There was a similar degree of variability in the older group, with more than half the participants wishing for something related to their own future well-being and the remainder being divided between those who expressed hedonistic wishes and those who wished for something to benefit others.

In examining the relation between wishes and expressions of gratitude, we found an inverse relation 
between hedonistic wishes and connective gratitude. Some scholars studying older adolescents and adults have reported an inverse relation between materialism and the expression of gratitude (Froh, Emmons, Card, Bono, \& Wilson, 2011; Lambert, Fincham, Stilman, \& Dean, 2009). To the extent to which a desire for things that give immediate pleasure is one component of materialism, our findings suggest that the issue might be more complex, at least with children and younger adolescents. Those participants who wished for something that would immediately benefit themselves were just as likely as others to express gratitude, but it was concrete gratitude that did not involve taking another person's wishes, needs, or desires into account. By contrast, those who wished for something that would benefit the wider community were more likely to express the sort of gratitude that involves connections with others. Although the older group was more likely than those who were younger to show both connective gratitude and social well-being, this inverse relation between hedonistic wishes and connective gratitude was found equally in the younger and older age groups.

In the adult literature, gratitude is linked to many indices of well-being. It is thus surprising that so little attention has been paid to the development of this positive characteristic. From a developmental perspective it is important to consider the implications of the existence of different types of gratitude. Saying "thank you" may be politeness and concrete gratitude may be a mark of a child's egocentric thinking whereas connective gratitude fulfills the required aspects of gratitude as defined by philosophers and psychologists. Specifically, connective gratitude encompasses both pleasure in the gift or help received and a desire to repay with something that is of benefit or pleasure to the benefactor. As its name suggests, connective gratitude is most likely to build or strengthen connections between benefactor and beneficiary. The vast majority of research on gratitude conducted with older adolescents and adults has focused on how much individuals express gratitude, regardless of the type of gratitude expressed or the source of the feeling of gratitude. Further research is needed to examine variations in the types of gratitude expressed across a range of contexts and situations.

Future studies will also need to go further and assess the development of gratitude longitudinally as well as examining precursors to individual differences in the expression of gratitude. No studies have so far examined ways in which parents encourage their children to feel and express gratitude. Similarly, more work is needed to understand the broader social contexts of social class, ethnicity, and culture, and the ways in which these contexts influence the development of gratitude. We had not expected to find racial/ethnic variations in the types of wishes expressed, yet we found more African American youths to express wishes for self well-being and fewer to express wishes for social well-being as compared with European American youths. Although our results are similar to those reported from Brazil by Freitas et al. (2011), more work is needed to determine whether these findings hold in other samples both within and outside the United States and, if so, to understand the source of these differences. Clearly, with data only collected from one part of the United States we would not wish to generalize our findings to other regions of the country or to other parts of the world (Tudge \& Freitas, 2012). We should also note that $44 \%$ of the permission letters sent home with the students did not come back to the school. This is not necessarily indicative of a high refusal rate; of those letters that came back (classrooms were promised $\$ 2$ for each letter returned, whether parents granted permission or not), only $16 \%$ indicated refusal. It is possible that the letters were simply lost en route. Unfortunately, we were unable to collect data on the socioeconomic backgrounds of the participants in our sample, but understanding the links with social class must be a priority for future work in this area. Moreover, research is needed to elucidate how gratitude develops in societies (and in cultural groups) in which parents are more closely connected with community and value relatedness as much as or more than autonomy (Kağitçibaşi, 2012).

The connection we found between wishes and gratitude is an interesting one, and something that needs further exploration. The data presented here are correlational, and given that the question regarding wishes preceded the question about gratitude, it might be that youths who have just expressed a wish about others' well-being are more ready to express connective gratitude than are those who think about their own immediate desires. Nonetheless, encouraging youth to feel and express connective gratitude might not only help strengthen ties with others and with the broader community but may also reduce the desire to satisfy hedonistic wishes. Regardless, it might be helpful for parents and teachers to encourage their children to express their gratitude not so much for the gift or help they received but to the person providing it, thereby supporting the development of connective gratitude. Similarly, these findings should be helpful to professionals seeking ways to encourage youth well-being and connection with others in the community.

\section{References}

Algoe, S. B. (2012). Find, remind, and bind: The functions of gratitude in everyday relationships. Social and Personality Psychology Compass, 6(6), 455-469. doi:10.1111/ 1j.1751-9004.2012.00439.x

Algoe, S. B., Fredrickson, B. L., \& Gable, S. L. (2013). The social functions of the emotion of gratitude via expression. Emotion, 13(4), 605-609. doi:10.1037/a0032701

Baumgarten-Tramer, F. (1938). "Gratefulness" in children and young people. Journal of Genetic Psychology, 53, 53-66.

Becker, J. A., \& Smenner, P. C. (1986). The spontaneous use of thank you by preschoolers as a function of sex, socioeconomic status, and listener status. Language in Society, 15(4), 537-546. doi:10.1017/ S0047404500012008

Bonnie, K. E., \& de Waal, F. B. M. (2004). Primate social reciprocity and the origin of gratitude. In R. A. Emmons \& M. E. McCullough (Eds.), The psychology of gratitude 
(pp. 213-229). New York, NY: Oxford University Press.

Bono, G., \& Froh, J. (2009). Gratitude in school: Benefits to students and schools. In R. Gilman, E. S. Huebner, \& M. J. Furlong (Eds.), Handbook of positive psychology in schools (pp. 77-88). New York, NY: Routledge.

Chaplin, L. N., \& John, D. R. (2007). Growing up in a material world: Age differences in materialism in children and adolescents. Journal of Consumer Research, 34(4), 480493.

Emmons, R. A., \& Mishra, A. (2012). Why gratitude enhances well-being: What we know, what we need to know. In K. M. Sheldon, T. B. Kashdan, \& M. F. Steger (Eds.), Designing the future of positive psychology: Taking stock and moving forward (pp. 248-264). New York, NY: Oxford University Press.

Freitas, L. B. L., O’Brien, M., Nelson, J. A., \& Marcovitch, S. (2012). A compreensão da gratidão e teoria da mente em crianças de 5 anos [The understanding of gratitude and theory of mind in 5-year-olds]. Psicologia: Reflexão e Crítica, 25(2), 330-338. doi:10.1590/S010279722012000200015

Freitas, L. B. L., Pieta, M. A. M., \& Tudge, J. R. H. (2011). Beyond politeness: The expression of gratitude in children and adolescents. Psicologia: Reflexão e Crítica, 24(4), 757-764. doi:10.1590/S0102-79722011000400016

Freitas, L. B. L., Tudge, J. R. H., \& McConnell, T. (2008). The wishes and gratitude survey (Adapted from BaumgartenTramer, 1938). Greensboro, NC. Unpublished questionnaire.

Froh, J. J., Bono, G., \& Emmons, R. (2010). Being grateful is beyond good manners: Gratitude and motivation to contribute to society among early adolescents. Motivation and Emotion, 34(2), 144-157.doi:10.1007/s11031-0109163-z

Froh, J. J., Bono, G., Fan, J., Emmons, R. A., Henderson, K., Harris, C., . . . Wood, A. M. (2014). Nice thinking! An educational intervention that teaches children to think gratefully. School Psychology Review, 43(2), 132-152.

Froh, J. J., Emmons, R. A., Card, N. A., Bono, G., \& Wilson, J. A. (2011). Gratitude and the reduced costs of materialism in adolescents. Journal of Happiness Studies, 12(2), 289-302. doi:10.1007/s10902-010-9195-9

Froh, J. J., Yurkewicz, C., \& Kashdan, T. B. (2009). Gratitude and subjective well-being in early adolescence: Examining gender differences. Journal of Adolescence, 32(3), 633-650. doi:10.1016/j.adolescence.2008.06.006

Goldberg, M. E., Gorn, G. J., Peracchio, L. A., \& Bamossy, G. (2003). Understanding materialism among youth. Journal of Consumer Psychology, 13(3), 278-288. doi:10.1207/ S15327663JCP1303_09

Gordon, A. K., Musher-Eizenman, D. R., Holub, S. C., \& Dalrymple, J. (2004). What are children thankful for? An archival analysis of gratitude before and after the attacks of September 11.Journal ofApplied DevelopmentalPsychology, 25(5), 541-553. doi:10.1016/j.appdev.2004.08.004

Gulliford, L., Morgan, B., \& Kristjánsson, K. (2013). Recent work on the concept of gratitude in philosophy and psychology. Journal of Value Inquiry, 47(3), 285-317. doi:10.1007/s10790-013-9387-8

Hardy, S. A., Walker, L. J., Olsen, J. A., Skalski, J. E., \& Basinger, J. C. (2011). Adolescent naturalistic conceptions of moral maturity. Social Development, 20(3), 562-586. doi:10.1111/j.1467-9507.2010.00590.x

Kağitçibaşi, C. (2012). Sociocultural change and integrative syntheses in human development: Autonomous-related self and social-cognitive competence. Child Development Perspectives, 6(1), 5-11. doi:10.1111/j.17508606.2011.00173.x

Kashdan, T. B., Mishra, A., Breen, W. E., \& Froh, J. J. (2009). Gender differences in gratitude: Examining appraisals, narratives, the willingness to express emotions, and changes in psychological needs. Journal of Personality, 77(3), 691-730. doi:10.1111/j.1467-6494.2009.00562.x

Kasser, T. (2005). Frugality, generosity, and materialism in children and adolescents. In K. A. Moore \& L. H. Lippman (Eds.), What do children need to flourish? Conceptualizing and measuring indicators of positive development (pp. 357-373). New York, NY: Springer.

Kawashima, R. A., \& Martins, R. A. (2015). The absence of generosity and obedience to authority: Judgments of teachers and students from kindergarten. Paidéia (Ribeirão Preto), 25(60), 115-123. doi:10.1590/198243272560201514

Kerr, S. L., O’Donovan, A., \& Pepping, C. A. (2015). Can gratitude and kindness interventions enhance well-being in a clinical sample? Journal of Happiness Studies, 16(1), 17-36. doi:10.1007/s10902-013-9492-1

Lambert, N. M., Fincham, F. D., Stilman, T. F., Dean, L. R. (2009). More gratitude, less materialism: The mediating role of life satisfaction. The Journal of Positive Psychology, 4(1), 32-42. doi:10.1080/17439760802216311

McConnell, T. (1993). Gratitude. Philadelphia, PA: Temple University Press.

McConnell, T. (2013). Gratitude. In H. LaFollette (Ed.), International encyclopedia of ethics (Vol. 4, pp. 22202229). Malden, MA: Wiley-Blackwell.

McCullough, M. E., Emmons, R. A., \& Tsang, J.-A. (2002). The grateful disposition: A conceptual and empirical topography. Journal of Personality and Social Psychology, 82(1), 112-127. doi:10.1037//0022-3514.82.1.112

McCullough, M. E., Kimeldorf, M. B., \& Cohen, A. D. (2008). An adaptation for altruism? The social causes, social effects, and social evolution of gratitude. Current Directions in Psychological Science, 17(4), 281-285. doi:10.1111/j.1467-8721.2008.00590.x

Nelson, J. A., Freitas, L. B. L., O’Brien, M., Calkins, S. D., Leerkes, E. M., \& Marcovitch, S. (2013). Preschool-aged children's understanding of gratitude: Relations with emotion and mental state knowledge. British Journal of Developmental Psychology, 31(1), 42-56. doi:10.1111/ j.2044-835X.2012.02077.x

Paludo, S. S. (2014). As emoções no universo moral 
dos adolescentes [Emotions in the moral universe of adolescents]. In L. F. Habigzang, E. Diniz, \& S. H. Koller (Orgs.), Trabalhando com adolescentes: Teoria $e$ intervenção psicológica [Working with adolescents: Psychological theory and intervention] (pp. 164-179). Porto Alegre, RS: Artmed.

Piaget, J. (1981). Intelligence and affectivity: Their relationship during child development. Palo Alto, CA: Annual Reviews. (Original work published 1954).

Rava, P. G. S., \& Freitas, L. B. L. (2013). Gratidão e sentimento de obrigatoriedade na infância [Gratitude and the feeling of obligation in childhood]. Psico-USF, 18(3), 383-394. doi:10.1590/S1413-82712013000300005

Tudge, J. R. H., \& Freitas, L. B. L. (2012). Internationalization, globalization and culture. Psicologia \& Sociedade, 24(3), 547-556. doi:10.1590/S0102-71822012000300008

Weiner, B., \& Graham, S. (1988). Understanding the motivational role of affect: Life-span research from an attributional perspective. Cognition and Emotion, 3(4), 401-419. doi:10.1080/02699938908412714

Wood, A. M., Froh, J. J., \& Geraghty, A. W. A. (2010). Gratitude and well-being: A review and theoretical integration. Clinical Psychology Review, 30(7), 890-905. doi:10.1016/j.cpr.2010.03.005

Jonathan Richard Henry Tudge is a Full Professor at the University of North Carolina at Greensboro, and a Collaborating Professor at the Universidade Federal do Rio Grande do Sul.

Lia Beatriz de Lucca Freitas is an Associate Professor at the Universidade Federal do Rio Grande do Sul.

Irina L. Mokrova is a Research Associate at the University of North Carolina at Chapel Hill.

Yudan Chen Wang is a Postdoctoral Researcher at the University of North Carolina at Greensboro.

Marion O'Brien is a Professor Emerita at the University of North Carolina at Greensboro.

Received: Oct. 17, 2014

1st Revision: Apr. 22, 2015

Approved: Apr. 27, 2015

How to cite this article:

Tudge, J. R. H., Freitas, L. B. L., Mokrova, I. L., Wang, Y. C., \& O'Brien, M. (2015). The wishes and expression of gratitude of youth. Paidéia (Ribeirão Preto), 25(62), 281288. doi:10.1590/1982-43272562201501 